\title{
Embracing Universal Design for Transformative Learning
}

\author{
DR LARRY MCNUTT ${ }^{\mathrm{a}}$ and DR GER CRADDOCK ${ }^{\mathrm{b}}$ \\ a Technological University Dublin \\ ${ }^{\mathrm{b}}$ Centre for Excellence in Universal Design
}

\begin{abstract}
The purpose of this paper is to introduce participants to our journey of integrating Universal Design as a central part of a new Technological University in addressing the challenge of a consistent quality experience for all learners. Adopting and combining both the principles of universal design and universal design for learning is not to make it easier but to offer a framework of principles and guidelines to make education appropriate and challenging for everyone. Ken Robinson wrote "A vibrant school can nourish an entire community by becoming a source of hope and creative energy......Poor schools can drain the optimism from all the students and families who depend on it by diminishing their opportunities for growth and development" (1)
\end{abstract}

Keywords. Universal design principles, universal design for Learning principles, transformation, higher education

\section{Introduction}

The paper is based on the long engagement of the Centre for Excellence in Universal Design with the development and implementation of the first Technological University in Ireland and the co-hosting of the Universal Design Conference Higher Education in Transformation (UDHEIT) Congress in 2018. The paper argues that now is an opportune time to consider a more organic model. A model which focuses on an ecological systems theory of human development and recognises the many layers of our environment, which influence our development (2). Central to the implementation of this system we suggest that a universal design approach can be the enabler to transform education from an inequitable learning environment for many students to a more holistic student centric experience.

The World Health Organisation (WHO) reports "systematic challenges" in global educational systems such as under resourced supports and an ad hoc division of responsibility across the government departments of education, health and social protection leading to an over focus on "special" supports rather than inclusion and equity (3). There has also been a lack of legislation and targets on inclusion compounded by school level barriers including physical access, inflexible and inappropriate curricula and pedagogy, inadequate teacher training and discriminatory attitudes, are seriously undermining inclusion and reinforcing marginalisation. Moreover, WHO argues that to address these significant problems, a paradigm shift is needed, moving away from just 'accessibility', which provides basic access and usability of facilities, products and services for people with disabilities to a UD approach that enables independence and social participation for all through continual improvement in all contexts. The WHO International Classification of Function (ICF) offers a person-centred system to 
understand the functional ability of learners entering education in different contexts through a useful distinction between "performance" and "capacity". Common to the ICF, UD and UDL focus on the interaction between person and environment (4). The United Nations Convention of the Rights of People with Disabilities (UNCRPD) has endorsed UD as the preferred approach towards inclusion and have advocated that it should frame national policies on the design of environments, products, services and information communication technologies.

\section{Method}

The format of the paper is to describe how the principles of universal design impact on the transformation agenda in education. Followed by examples of how these principles are mainstreamed into the structures of a new university from a systems framework and what are the next steps to ensuring that it is expanded beyond the walls of the university to become national policy.

The concept of UD can be traced back to the internationally recognised architect, product designer and educator Ron Mace in the USA in the 1970s. Mace himself a wheelchair user, believed that if architects should design environments to be "usable by everyone to the greatest extent possible". Mace and his colleagues developed the Seven Principles of Universal Design to guide better and more inclusive design of environments, products and information communication technologies (ICT). These principles are now widely used across the globe and here in Ireland and are the bedrock of the Centre for Excellence in Universal Design (CEUD) ${ }^{1}$ which was established through legislation in 2005. The legislation defines UD as.

"the design and composition of an environment so that it can be accessed, understood and used to the greatest extent possible by all people regardless of their age, size, ability or disability." in brief the seven principles are:

\begin{tabular}{|l|l|}
\hline Equitable use & $\begin{array}{l}\text { Design is accessible and useful for people with diverse abilities. } \\
\text { e.g. Information, products and services in formats accessible for } \\
\text { a broad range of abilities, disabilities, ages, racial, and ethnic } \\
\text { backgrounds. }\end{array}$ \\
\hline Flexibility in use & $\begin{array}{l}\text { Design accommodates a wide range of individual preferences } \\
\text { and abilities, e.g.: the design provides a choice to read or listen } \\
\text { in class or through a digital recording of the text book. }\end{array}$ \\
\hline $\begin{array}{l}\text { Simple \& } \\
\text { intuitive }\end{array}$ & $\begin{array}{l}\text { Design is easy to understand, regardless of the user's } \\
\text { experience, knowledge, language skills, or current concentration } \\
\text { level, e.g. Testing in a predictable, straightforward manner. }\end{array}$ \\
\hline $\begin{array}{l}\text { Perceptible } \\
\text { information }\end{array}$ & $\begin{array}{l}\text { Design communicates necessary information effectively to the } \\
\text { user, regardless of ambient conditions or the user's sensory } \\
\text { abilities. e.g. An emergency alarm system with visual, aural, and } \\
\text { kinaesthetic characteristics. }\end{array}$ \\
\hline $\begin{array}{l}\text { Tolerance for } \\
\text { error }\end{array}$ & $\begin{array}{l}\text { Design minimizes hazards and the adverse consequences of } \\
\text { accidental or unintended actions e.g.: A software program that }\end{array}$ \\
\hline
\end{tabular}

${ }^{1}$ CEUD www.universaldesign.ie 


\begin{tabular}{|c|c|}
\hline & $\begin{array}{l}\text { provides guidance when the student makes an inappropriate } \\
\text { selection. }\end{array}$ \\
\hline $\begin{array}{l}\text { Low physical } \\
\text { effort }\end{array}$ & $\begin{array}{l}\text { Design can be used efficiently and comfortably and with a } \\
\text { minimum of fatigue, e.g. Software with on-screen control } \\
\text { buttons that are large enough for students with limited fine } \\
\text { motor skills to select easily. }\end{array}$ \\
\hline $\begin{array}{l}\text { Size and space } \\
\text { for approach and } \\
\text { use }\end{array}$ & $\begin{array}{l}\text { Appropriate size and space is provided for approach, reach, } \\
\text { manipulation, and use regardless of the user's body size, } \\
\text { posture, or mobility, e.g. An adjustable table and work area that } \\
\text { is usable by students who are right- or left-handed or have a } \\
\text { wide range of physical characteristics and abilities. }\end{array}$ \\
\hline Equitable use & $\begin{array}{l}\text { Design is accessible and useful for people with diverse abilities. } \\
\text { e.g. Information, products and services in formats accessible for } \\
\text { a broad range of abilities, disabilities, ages, racial, and ethnic } \\
\text { backgrounds. }\end{array}$ \\
\hline Flexibility in use & $\begin{array}{l}\text { Design accommodates a wide range of individual preferences } \\
\text { and abilities, e.g.: the design provides a choice to read or listen } \\
\text { in class or through a digital recording of the text book. }\end{array}$ \\
\hline $\begin{array}{l}\text { Simple \& } \\
\text { intuitive }\end{array}$ & $\begin{array}{l}\text { Design is easy to understand, regardless of the user's } \\
\text { experience, knowledge, language skills, or current concentration } \\
\text { level, e.g. Testing in a predictable, straightforward manner. }\end{array}$ \\
\hline $\begin{array}{l}\text { Perceptible } \\
\text { information }\end{array}$ & $\begin{array}{l}\text { Design communicates necessary information effectively to the } \\
\text { user, regardless of ambient conditions or the user's sensory } \\
\text { abilities. e.g. An emergency alarm system with visual, aural, and } \\
\text { kinaesthetic characteristics. }\end{array}$ \\
\hline $\begin{array}{l}\text { Tolerance for } \\
\text { error }\end{array}$ & $\begin{array}{l}\text { Design minimizes hazards and the adverse consequences of } \\
\text { accidental or unintended actions e.g.: A software program that } \\
\text { provides guidance when the student makes an inappropriate } \\
\text { selection. }\end{array}$ \\
\hline $\begin{array}{l}\text { Low physical } \\
\text { effort }\end{array}$ & $\begin{array}{l}\text { Design can be used efficiently and comfortably and with a } \\
\text { minimum of fatigue, e.g. Software with on-screen control } \\
\text { buttons that are large enough for students with limited fine } \\
\text { motor skills to select easily. }\end{array}$ \\
\hline $\begin{array}{l}\text { Size and space } \\
\text { for approach and } \\
\text { use }\end{array}$ & $\begin{array}{l}\text { Appropriate size and space is provided for approach, reach, } \\
\text { manipulation, and use regardless of the user's body size, } \\
\text { posture, or mobility, e.g. An adjustable table and work area that } \\
\text { is usable by students who are right- or left-handed or have a } \\
\text { wide range of physical characteristics and abilities. }\end{array}$ \\
\hline
\end{tabular}

A UD system recognises the multiple layers within the ecological framework that effect human development and in particular within the educational ecosystem at a

- $\quad$ Micro level - Individual needs and abilities catered through teaching practices, classroom design and layout, technologies including assistive technologies. Learning resources and spaces, shifting the focus of education from institutional to individual learners, re-orientating the education towards the user and user involvement in the co-design of their own education. 
- Meso level - institution level - covering governance, policies and procedures as well as linking to families and community-based initiatives, now known to be critical for growing and sustaining innovative learning.

- Macro level -, establishing directives, legislative acts, developing standards, promoting awareness and ensuring the diffusion of universal design and its adoption at national and local educational system levels.

Universal Design for Learning (UDL) was introduced into education by the work of Rose and Meyer (5) who recognised that many of the resources and adaptations needed for students with disabilities could be applied across the curriculum and would benefit all students. They wanted to improve education, for all learners, through innovative uses of modern multimedia technology and contemporary research in the cognitive neurosciences. UDL is a proactive method for designing and delivering flexible approaches to teaching and learning, it recognises that all students bring to the classroom unique social and academic backgrounds and that disability lies not within the individual, but rather environments that are disabling. By understanding the "Why", the "What" and the "How" of learning, it is possible to design, materials and methods to accommodate all learners with a diverse range of abilities, characteristics and preferences without the need to retrofit or remove the student from the classroom. Based on UD, the principles of UDL provide a framework to ensure

- Multiple means of representation-give learners various ways of acquiring information and knowledge

- Multiple means of expression-provide learners alternatives for demonstrating what they know

- Multiple means of engagement-tap into learners' interests, offer appropriate challenges, and increase motivation

In "Reach Everyone, Teach everyone" (5) Tobin and Behling argue that universal design can enable many schools, colleges and universities from simply "doing inclusion" or "doing diversity" to an inclusive learning experience that benefits all students, reducing barriers to learning while still maintaining academic rigor. These principles when applied in whole or in part can have profound effects on the lives, experiences and expectations of learners

In "Reach Everyone, Teach everyone" (6) Tobin and Behling argue that universal design can enable many schools, colleges and universities from simply "doing inclusion" or "doing diversity" to an inclusive learning experience that benefits all students, reducing barriers to learning while still maintaining academic rigor. These principles when applied in whole or in part can have profound effects on the lives, experiences and expectations of learners

\section{Progress towards Designing a New Technological University}

Irish higher education has been afforded an opportunity to transform the current model of HE provision in the design of our first Technological University. This design initiative is tasked with developing an organisational design that enables $\mathrm{TU}$ Dublin to successfully deliver the objectives set out in the Strategic Intent 2030 document. The 
vision of the University is to 'Create a Better World Together'. The three pillars of the strategy are People, Planet and Partnership:

- People: Fostering Individual talents in an ever-changing world

- Planet: A powerhouse for living \& breathing

- Partnership: delivering shared impact

However, if we build our "new" design on the current structures that persist - we will simply reproduce the inequalities that are ingrained in our funding models and policies. The old premise on which we base our approach to HE provision is one that promotes a "deficit" model of our learners - an adherence to a view of "normal" and an insistence that anyone outside the "Normal" must be labelled.

Instead we need the heart of Universal Design reflected in our organisational structures - there is too much "sameness" - and the rules of engagement are akin to a sporting fixture with winners/losers, badges of success, league tables, limited measures of performativity that encourage a neo-liberal managerial culture.

Several current initiatives augur well for this ambition at a macro level with the principles of universal design and universal design for learning embedded in key frameworks:

1. An education model that is inclusive and student centred.

2. A unitary quality framework that governs all academic quality assurance and enhancement procedures and assessment regulations for TU Dublin.

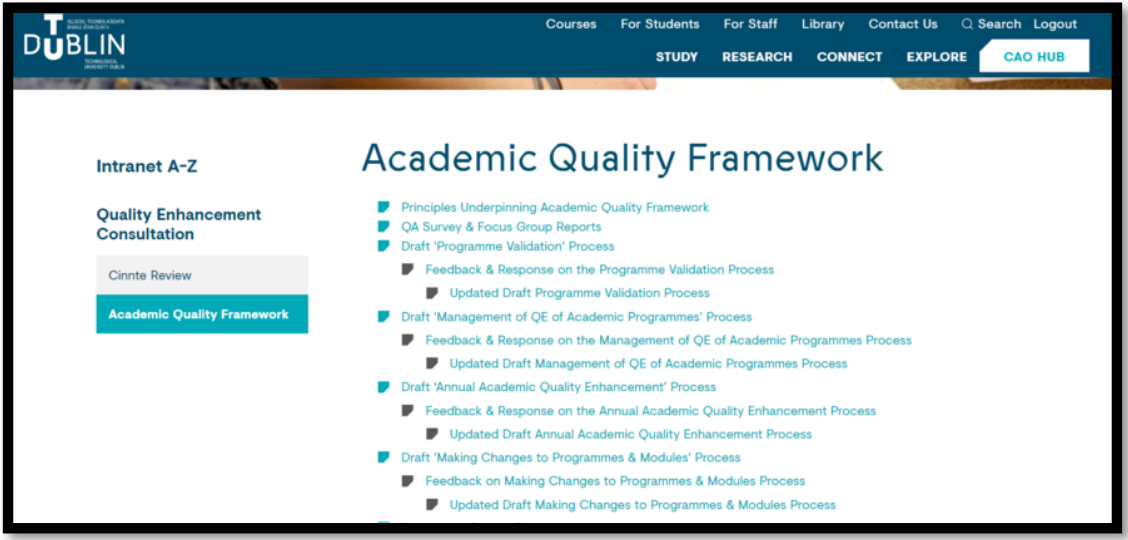

Figure 1: TUDublin Academic Quality Framework

3. An Equality, Diversity and Inclusion framework that seeks to embed universal design thinking into decision-making in TU Dublin: Equality and Diversity | TU Dublin

4. A European University of Technology model that has at its core a vision of "Think Human First": 


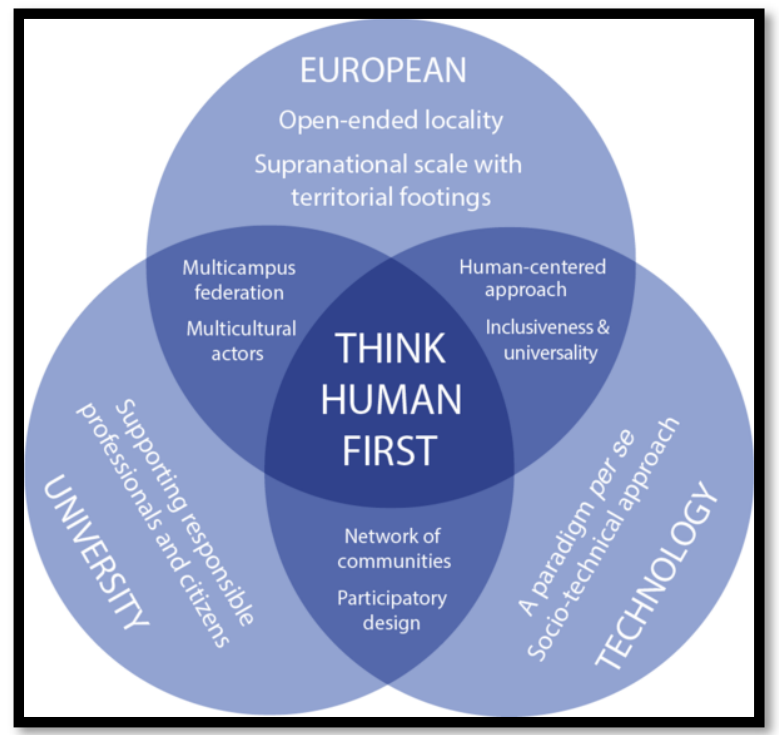

Figure 2 Vision EUt+ - Université de Technologie Européenne (univ-tech.eu)

\section{Conclusion and lessons learned}

In conclusion we argue that responding to these design challenges as a collective rather than a hyper-competitive HE sector is worthy of greater consideration. To achieve this ambition, we must bridge the "know-do" gap, knowing how to do something is easy today - but being prepared to bring a potentially magical experience to our audience of learners is very different. This was a key theme of the international congress, Universal Design \& Higher Education in Transformation, held in Dublin in $2018^{2}$. We must be committed, connected and generous and design the equivalent of the "wild Atlantic way" of educational experiences for all our learners (7). Ireland's newest University designed it's new campus on UD principles and - the Technological University Dublin was honoured to receive the "Recognition of Excellence Award" from CEUD in recognition of the accomplishment of its three founding institutions; IT Blanchardstown, DIT and IT Tallaght and the ongoing commitment of the University to continue to embed UD at a macro, meso and micro level.

This is an ambitious agenda at an important juncture in Irish history. How we address the inherent systemic inequalities in our design of education provision will have profound implications for generations to come. To bring about the necessary change, our response must be emotional - we must feel the need for change and challenge our own values, beliefs and assumptions. Therefore, the work of designers must be informed by the experience of educational designers and developers and where policy makers and educational leaders must collectively engage and seek out the influence of the design community. If good design truly enables the hearts, minds and souls of learners it must be front and centre of all endeavours to transform our education system.

\footnotetext{
${ }^{2}$ www.udheit2018.com
} 


\section{References}

[1] Robinson, Ken (2015) Creative schools, Random House Publishing

[2] Bronfenbrenner, Uri (1979) The Ecology of Human Development, Harvard University Press

[3] World Health Organisation (2011) World Report on Disability: World Health Organisation

[4] Bencici Giulia, Garofolo Ilaria \& Alberto Arenghi (2018) Implementing Universal Design and the ICF in Higher Education in Transforming our World Through Design, Diversity and Education G. Craddock et al. (Eds.) IOS press

[5] Rose, D. and Meyer, A. (2005) The Universally Designed Classroom: Accessible Curriculum and Digital Technologies. Harvard Education Press.

[6] Tobin, Thomas \& Kirsten Behling (2019) Reach Everyone, Teach everyone. West Virginia University Press

[7] McNutt, Larry. Reframing Higher Education, the Wild Atlantic Way A Personal Reflection. All Ireland Journal of Higher Education, [S.1.], v. 7, n. 1, feb. 2015. 